* Possui graduação em Direito pela Universidade Estadual de Maringá. Pós Graduada em Direito do Trabalho e Direito Previdenciário pela Universidade Estadual do Norte do Paraná. Advogada. marcelapires@hpadv.com.br

** Possui pós-doutorado em Direito, pela Universidade de Lisboa-Portugal. Doutorado em Direito pela Pontifícia Universidade Católica de São Paulo. Mestrado em Direito pela Pontifícia Universidade Católica de São Paulo. Graduação em Direito pela Fundação Universidade Estadual de Maringá Professora da graduação em Direito da Universidade Estadual de Maringá (UEM), do Mestrado, Especialização e Graduação do Centro Universitário de Maringá-UNICESUMAR. formação.lemad@uol.com.br

\section{O Assédio Moral E A INVERSÃo do ôNUS da Prova}

Moral Harassment and Burden of Proof INVERSION

\section{Marcela Sandri Pires* Leda Maria Messias da Silva**}

Comocitar:PIRES, Marcela Sandri.SILVA,Leda Maria Messias da. O assédio moral e a inversão do ônus da prova. Revista do Direito Público, Londrina, v. 12, n. 2, p. 216-249, ago. 2017. DOI: $10.5433 / 1980-511 X .2017 v 12 n 2 p 216$

Resumo: O presente trabalho aborda a dificuldade de comprovação judicial do assédio moral no âmbito laboral, visando apontar uma solução para abolir o assédio e possibilitar a reparação das vítimas. Para tanto analisarse-á o meio ambiente de trabalho, o direito da personalidade, o assédio moral e o ônus da prova no processo trabalhista com base em pesquisa teórica e descritiva, abordando o tema através do método dedutivo, apresentando como conclusão a proposta para possibilitar a inversão do ônus da prova na comprovação do assédio moral.

Palavras-chave: Dignidade da pessoa humana. Meio Ambiente do Trabalho. Assédio moral. Ônus da prova.

Abstract: This paper addresses the difficulty of proving judicial moral harassment in the 
work environment, aiming to find a solution to abolish harassment and make reparationfor victims. For this purpose, will be analyzed the work environment, personality rights, moral harassment and the burden of proof in the labor process, based on theoretical and descriptive research, approaching the subject through the deductive method, presenting as a conclusion the proposal to enable the reversal of the burden of proof in proving moral harassment.

Key words: Dignity of human person. Work Environment. Moral Harassment. Burden of proof. 


\section{INTRODUÇÃO}

O assédio moral no âmbito trabalhista é uma conduta abusiva que expõe o trabalhador a situações humilhantes e constrangedoras, reiteradamente, desiquilibrando o meio ambiente laboral, agredindo os direitos da personalidade e, consequentemente, a dignidade humana do trabalhador, causando-lhe sérias consequências à saúde física, psicológica e moral.

Devido à dificuldade de comprovação da conduta do agressor, seja pela possível ausência de testemunhas durante a violência devido ao fato do assédio geralmente ser velado, seja pelo temor dos que presenciaram o ato em depor em desfavor de seu empregador, a vítima, quando decide lutar contra o assédio, encontra dificuldades em exercer o ônus comprobatório no âmbito judicial, por vezes desistindo de exigir seus direitos, outras não logrando êxito perante a justiça trabalhista.

Diante da dificuldade da vítima em comprovar o ocorrido e da necessidade de se abolir a prática do assédio moral no âmbito trabalhista, o presente trabalho almeja apontar uma solução para cessar o assédio moral no ambiente de trabalho, apresentando a possibilidade de inversão do ônus da prova, em juízo, como forma de transferir ao empregador o ônus de comprovar a higidez do ambiente de trabalho.

Para tanto, o estudo em questão, foi realizado através de pesquisa teórica e descritiva em livros, dissertações, artigos, legislações e jurisprudência, sendo abordado por meio do método dedutivo, por fornecer uma base lógica ao tema, o qual partirá de teorias gerais para as mais específicas, primeiramente analisando o meio ambiente do trabalho e os direitos da personalidade, posteriormente adentrando no tema assédio moral, apresentando seu conceito, requisitos, classificação, bem como 
suas consequências ao trabalhador.

Por fim, para análise da inversão do ônus da prova na comprovação do assédio moral, tratar-se-á das provas em sentido amplo, após, especificar-se-á a questão do ônus da prova no âmbito trabalhista e finaliza-se com o estudo da possibilidade da inversão do ônus da prova em situações de assédio moral, concluindo-se por sua viabilidade e sua contribuição na prevenção deste mal, defendendo e preservando o meio ambiente do trabalho.

\section{MEIO AMBIENTE DO TRABALHO E OS DIREITOS DA PERSONALIDADE}

$\mathrm{O}$ conceito de meio ambiente encontra-se definido legalmente na Lei 6.938/91, artigo $3^{\circ}$, inciso I, correspondendo ao "[...] conjunto de condições, leis, influências e interações de ordem física, química e biológica, que permite, abriga e rege a vida em todas as suas formas" (BRASIL, 1991).

Embora não conste nenhuma definição na Constituição Federal de 1988 (BRASIL, 1988), o artigo 225 da Constituição da República garante a todos um meio ambiente ecologicamente equilibrado, tutelando diretamente a qualidade do meio ambiente e indiretamente a saúde, o bem estar e a segurança da população.

Conforme leciona Fiorillo e Rodrigues (1997, p. 27-28),

O direito ao meio ambiente, em verdade, é pressuposto de exercício lógico dos demais direitos do homem, vez que, sendo o direito à vida o objeto do direito ambiental, somente aqueles que possuírem vida, e, mais ainda, vida com qualidade e saúde, é que 
terão condições de exercitarem os demais direitos humanos, nestes compreendidos os direitos sociais, da personalidade e políticos do ser humano.

Assim, o meio ambiente equilibrado é essencial para o exercício de todos os direitos humanos, razão pela qual se impõe ao poder público e à coletividade o dever de defendê-lo e preservá-lo, garantindo a todas as gerações uma vida digna em qualquer ambiente em que estiverem, seja ele natural, artificial, cultural ou do trabalho.

O meio ambiente do trabalho, como o próprio termo reporta, corresponde ao local onde se desenvolve o exercício da atividade laboral, remunerada ou não, integrando não apenas o espaço físico em que a atividade é realizada, mas os instrumentos de trabalho, a forma de execução das tarefas, o tratamento dos colegas e superiores hierárquicos e demais elementos que compõe o ambiente de trabalho.

Leda Maria Messias da Silva (2008, p. 107), afirma com propriedade que,

Deve-se compreender como meio ambiente do trabalho não só o local onde o trabalhador presta o seu serviço, mas também como parte do meio ambiente do trabalho, todos os fatores internos ou externos que possam interagir com o trabalho e influenciar de alguma forma esse meio ambiente, contribuindo para o seu equilíbrio ou desiquilíbrio.

Enaltecendo a importância da qualidade do ambiente de trabalho, Amauri Mascaro do Nascimento (1999, p. 584) incorpora na definição do termo diversos direitos trabalhistas que garantem um ambiente de trabalho digno, discorrendo que, 
[...] meio ambiente de trabalho é, exatamente, o complexo máquina-trabalho; as edificações, do estabelecimento, equipamentos de proteção individual, iluminação, conforto térmico, instalações elétricas, condições de salubridade ou insalubridade, de periculosidade ou não, meios de prevenção à fadiga, outras medidas de proteção ao trabalhador, jornadas de trabalho e horas extras, intervalos, descansos, férias, movimentação, armazenagem e manuseio de materiais que formam o conjunto de condições de trabalho etc.

Devido ao longo período em que o ser humano encontrase no habitat laboral provendo o necessário para sua sobrevivência e desenvolvimento, o equilíbrio do meio ambiente do trabalho é indispensável na garantia da qualidade de vida do trabalhador e de sua dignidade no exercício laboral, devendo, portanto, priorizar a proteção à saúde física, psíquica e social dos trabalhadores, sendo salubre, saudável, digno e integro (RUFINO, 2011, P. 40-41).

Em um meio ambiente do trabalho equilibrado, que proporcione um emprego decente, há plena concretização dos direitos humanos do trabalhador, nestes compreendidos seus direitos da personalidade, direitos essenciais ao desenvolvimento do homem, que resguardam a dignidade da pessoa humana.

Doutrinariamente os direitos da personalidade apresentam diferentes conceitos, sendo tratados pelos autores positivistas [De Cupis e Tobeñas] como direitos intimamente relacionados à personalidade, inatos, mas que assumem o caráter de essencialidade somente após seu reconhecimento pelo Estado; por outro lado os naturalistas [Limongi 
França e Bittar] consideram-nos como os direitos que se relacionam com atributos inerentes à condição humana, correspondentes às faculdades exercidas naturalmente pelo homem, sem necessidade do reconhecimento estatal (BITTAR, 2015, p. 25-26).

Independentemente do posicionamento adotado, Bittar (2015, p. 28) destaca em sua obra que, tanto positivistas quanto naturalistas

[...] tem proporcionado a possibilidade de afirmar na dignidade da pessoa humana, decorrente da Constituição de 1988, e decorrente da Declaração Universal dos Direitos Humanos de 1948, a forma pela qual se dá tratamento e se confere fundamentação aos direitos humanos, aos direitos fundamentais e por consequência, aos direitos da personalidade.

Pautado na dignidade da pessoa humana, os direitos da personalidade resguardam direitos físicos, psíquicos e morais do homem, tutelando o ente individual, com seu patrimônio físico e intelectual, sua posição perante outros seres na sociedade, seu modo de ser e suas projeções na coletividade, garantindo a todos uma vida digna com respeito a atributos essenciais ao ser humano.

Segundo Bitencourt (2012, p. 54), “[...] os direitos da personalidade são plenamente aplicáveis às relações trabalhistas, pois sem esses o trabalhador não teria assegurada a sua dignidade enquanto pessoa", sendo indispensáveis na tutela do ataque na esfera privada do trabalhador, eis que tutelam os interesses do empregado frente ao empregador.

Resguardando a personalidade do trabalhador frente às práticas adotadas no mercado de trabalho, afastam-se os riscos e perigos existentes no meio ambiente do trabalho, protegendo não apenas a integridade física, 
psíquica, moral e o bem-estar durante o labor, mas também sua qualidade de vida fora do local de trabalho, eis que o que ocorre durante a jornada de trabalho reflete na vida social e familiar do obreiro.

Desta forma, para a obtenção do meio ambiente equilibrado tutelado pela Constituição Federal, essencial à sadia qualidade de vida, necessário se faz a manutenção de meio ambiente do trabalho decente e digno, que respeite os direitos da personalidade dos trabalhadores, protegendo-os de condutas abusivas, tais como o assédio moral, uma prática repugnante que afeta os direitos personalíssimos do trabalhador, ocasionando consequências nefastas à sua saúde física, psicológica e moral, lesando, consequentemente, os pilares fundamentais do estado democrático de Direito: a dignidade da pessoa humana e o valor social do trabalho [CF, art. $1^{\circ}$, incisos III e IV].

\section{ASSÉDIO MORAL}

Em nosso ordenamento pátrio não há previsão específica sobre o assédio moral, cabendo à doutrina e à jurisprudência a definição do conceito do termo, que de uma forma mais ampla é conceituado pela pesquisadora francesa, psiquiatra e psicanalista Hirogoyen (2012, p. 17) como, "[...] qualquer conduta abusiva (gesto, palavra, comportamento, atitude...) que atente, por sua repetição ou sistematização, contra a dignidade ou integridade psíquica ou física de uma pessoa, ameaçando seu emprego ou degradando o clima de trabalho".

No âmbito nacional a intencionalidade apontada pela pesquisadora francesa perde destaque, evidenciando-se o propósito de humilhar a vítima, conforme se observa na definição apresentada por Delgado (2013, p. 650), 
[...] conduta reiterada seguida pelo sujeito ativo no sentido de desgastar o equilíbrio emocional do sujeito passivo, por meio de atos, palavras, gestos e silêncios significativos que visem ao enfraquecimento e diminuição da autoestima da vítima ou a outra forma de tensão ou desequilíbrio emocionais graves.

Como se pode notar, o assédio moral caracteriza-se por uma conduta reiterada do ofensor, através de gestos, palavras, constrangimento, desvalorização, excesso de trabalho ou até mesmo o ócio compulsório, enfim, atitudes abusivas ou hostis que humilhem a vítima, que desrespeitem os direitos da personalidade do ofendido, atingindo sua dignidade.

Neste aspecto, Silva e Carvalho (2013, p. 23-25) caracterizam o assédio moral por:

a) Uma lesão à dignidade pessoal ou integridade moral do indivíduo assediado (bem jurídico protegido). O assédio moral é muito mais que uma mera perturbação na tranquilidade do sossego, ele constitui uma forma de atentado à integridade moral da pessoa humana $[. .$.

b) Um elemento objetivo, qual seja, o comportamento hostil do assediador, caracterizado por sua habitualidade e aptidão para humilhar a vítima assediada. Nesse sentido, insta salientar que os comportamentos constitutivos de assédio geralmente consistem em uma série de atuações hostis que, consideradas de forma isolada, poderiam parecer insignificantes, mas cuja repetição é justamente o que gera efeitos perniciosos.

c) Um elemento subjetivo, que genericamente deve ser entendido como propósito de subjugar a vontade da vítima com a finalidade específica de humilhá-la, desprezá-la e evitá-la. 
Em decorrência do desequilíbrio emocional sofrido pela vítima, muitas vezes o pedido de demissão decorre do assédio moral, no entanto, a ameaça do emprego e a degradação do clima de trabalho nem sempre é a finalidade do assediador, mas consequências decorrentes da violência cometida com o assediado.

Dentre as consequências do assédio moral, Barreto (2000) aponta em sua dissertação uma jornada de humilhações uma pesquisa realizada com 870 homens e mulheres vítimas de opressão no meio ambiente do trabalho, revelando como cada sexo reage ao assédio moral, destacando-se dentre os sintomas o fato de $100 \%$ dos homens terem a ideia de suicídio e $18,3 \%$ praticarem sua tentativa, bem como o fato de $80 \%$ de homens e mulheres terem dores generalizadas e $60 \%$ das mulheres e $70 \%$ dos homens sofrerem de depressão.

Diante de consequências tão alarmantes, o combate ao assédio moral é medida que se impõe ao poder público e à coletividade como forma de manter um meio ambiente de trabalho ecologicamente equilibrado, protegendo os direitos da personalidade do trabalhador, garantindo uma maior liberdade de trabalho e sua consequente satisfação, tutelando a vida, a integridade física e psicológica do empregado, resguardando, assim, a dignidade do trabalhador.

Apesar das consequências nefastas ocasionadas ao homem médio em decorrência do assédio moral, salientamos que o dano causado à vítima não pode ser considerado elemento constitutivo do assédio, devendo ser avaliada a conduta do ofensor em face da dignidade da pessoa humana, não os reflexos surtidos na vítima, pois a necessidade de um dano para evitar a conduta lesiva aos direitos da personalidade poderia causar isenção da responsabilidade do agressor (SILVA, 2015, p. 37). 
De igual forma, o assédio moral no meio ambiente do trabalho não corresponde apenas à conduta dos chefes em direção aos subordinados - assédio moral vertical em sentido descendente - caracterizando-se também a conduta oriunda de subordinados em relação à chefia - assédio moral vertical ascendente - e de colegas sobre outros colegas - assédio moral horizontal, podendo existir, ainda, uma forma mista entre as diversas classificações apontadas.

$\mathrm{O}$ assédio moral organizacional/institucional, por sua vez, ocorre quando a própria organização empresarial ou pública tem como política interna o assédio moral, sendo conceituado por Araujo (2007, p. 213-214) como "[...] a prática reiterada e frequente de variadas condutas abusivas, sutis ou explícitas contra uma ou mais vítimas, dentro do ambiente de trabalho, que, por meio do constrangimento e humilhação, visa controlar a subjetividade dos trabalhadores", abrangendo o controle da subjetividade

[...] a anuência a regras implícitas ou explícitas da organização, como cumprimento de metas, tempo de uso do banheiro, método de trabalho, até a ocultação de medidas ilícitas, como a sonegação de direitos (registro em Carteira de Trabalho, horas extras, estabilidade no emprego) ou o uso da corrupção e poluição pela empresa.

Independentemente da forma como é cometido o assédio moral, a atitude do agressor ofende os direitos da personalidade do empregado, correspondendo a uma afronta à dignidade e aos direitos individuais $\mathrm{e}$ sociais do trabalhador, segundo Rufino (2011, p. 44),

Existe um liame entre o assédio moral e a usurpação dos direitos da personalidade, da liberdade, da dignidade e do exercício da cidadania, pois as condutas vexatórias que configuram a violência 
perversa, denominada assédio moral, fatalmente ferirá o princípio maior dos cidadãos e dos demais direitos ligados à sua moral.

Assim, ante a flagrante ofensa aos fundamentos de nosso Estado Democrático de Direito, em especial à dignidade da pessoa humana e o valor social do trabalho, o assédio moral no âmbito trabalhista deve ser abolido, adotando-se condutas que desestimulem sua prática, como a inversão do ônus da prova no âmbito judicial, prática que facilitará a busca da verdade real através da análise do meio ambiente laboral, compelindo o empregador a manter um ambiente hígido e comprovar sua existência em juízo.

\section{A INVERSÃO DO ÔNUS DA PROVA NA COMPROVAÇÃO DO ASSÉDIO MORAL}

Para uma melhor compreensão da inversão do ônus da prova em situações de assédio moral, primeiramente tratar-se-á das provas de uma forma geral, apontando sua importância, objeto, objetivo e as situações em que são admitidas a inversão do ônus probatório, após será especificada a questão do ônus da prova no âmbito trabalhista e finalizase com o estudo principal da possibilidade da inversão do ônus da prova em situações de assédio moral.

\subsection{DAS PROVAS EM SENTINDO AMPLO}

Na ciência jurídica o termo "prova” possui várias acepções, podendo se referir à "produção de prova", ao "meio de prova" e, ainda, ao "convencimento do Juiz" (LEITE, 2008, p. 554), correspondendo 
ao mecanismo para se demonstrar a verdade ou não da existência e verificação de um fato jurídico em um processo, convencendo o magistrado e definindo o destino da relação jurídica.

Amauri Mascaro Nascimento (2007 apud SCHIAVI, 2016, p. 660-661) entende que,

A prova tem a finalidade de transportar, para o processo judicial, a realidade externa dos fatos que geraram a demanda, traduzindo-os para que possam ser conhecidos pelo juiz e para que sirvam de base para os debates entre as partes. Como meio destinado a levar para o processo a reconstrução dos fatos, poderá ter falhas e não cumprir com exatidão esse fim, situação na qual haverá a verdade real (concreta) diferente da realidade formal (imaginária), e esta prevalecerá. De nada adianta ter ocorrido ou não um fato se não pode ser provado. Desse modo, a importância da prova e da sua análise pelas partes e pelo juiz é fundamental para que o processo possa cumprir seus fins.

Devido a importância das provas no processo, o direito de produzir todas as provas permitidas em lei encontra-se previsto em nossa Constituição Federal no rol dos direitos e garantias fundamentas, artigo, $5^{\circ}$, inciso LV, sendo assegurado o contraditório e a ampla defesa, de forma que toda prova produzida por uma parte será cientificada à parte contrária, concedendo-lhe a oportunidade de impugná-la.

Visando resguardar o princípio da legalidade, a Constituição Federal veda a obtenção de provas ilícitas (CF, art. 5º inciso LVI), admitindo-as no âmbito trabalhista apenas em situações excepcionais na busca da verdade real, com fundamento no princípio da proporcionalidade, conforme adiante será abordado. 
O objeto da prova, por sua vez, são os fatos relevantes, pertinentes e controvertidos, não sendo preciso, nos termos do artigo 374 do Código de Processo Civil, submeter-se a atividade probatória os fatos notórios, afirmados por uma parte e confessados pela parte contrária, admitidos no processo como incontroversos ou em cujo favor milita presunção legal de existência ou veracidade, eis que já comprovados, tornando a atividade inútil.

De igual forma não é objeto da prova o direito em si, estando consagrado em nosso sistema processual o apotegma da mihi factum, dabo tibi jus [dá-me o fato, dar-te-ei o direito]. Todavia, em alguns casos excepcionais cabe a parte demonstrar o teor e a vigência de determinadas espécies normativas, na seara do processo do trabalho são exemplos: os acordos e convenções coletivas, regulamentos de empresas, dentre outras.

O objeto da prova, portanto, corresponde aos fatos que levam ao reconhecimento do direito da parte, cabendo a cada um dos litigantes demonstrar a veracidade de suas alegações e a falsidade das afirmações adversaria, de forma que a comprovação dos fatos conduzam ao julgamento favorável de sua demanda.

Ainda que cada parte do processo tenha o interesse em demonstrar a veracidade de suas alegações, há situações em que determinados fatos deixam de ser comprovados, circunstância em que será analisado a quem pertencia o ônus comprobatório, ou seja, quem tinha o dever de realizar a comprovação do fato controverso.

Conforme leciona Dinamarco e Lopes (2016, p. 183), a distribuição do ônus da prova é realizada com base no critério do interesse, incumbindo o ônus da prova ao autor quanto ao fato constitutivo de seu direito, e ao réu quanto à existência de fato impeditivo, modificativo ou extintivo do direito do autor, nos termos do artigo 373 do código 
de processo civil, considerando-se a alegação não comprovada como inexistente.

No entanto, em situações específicas se admite a inversão do ônus da prova, como, por exemplo, com a aplicação do artigo $6^{\circ}$, inciso VIII, do Código de Defesa do Consumidor, que dispõe ser direito do consumidor a facilitação da defesa de seus direitos com a inversão do ônus da prova " [...] quando, a critério do Juiz, for verossímil a alegação ou quando for ele hipossuficiente, segundo as regras ordinárias de experiência" (BRASIL, 1990).

Com o advento do novo Código de Processo Civil, a "distribuição dinâmica" do ônus comprobatório passou a ser admitida em situações que não envolvam relações de consumo, admitindo-se, com fulcro no artigo 373, $\S 1^{\circ}$, do Código de Processo Civil, que,

[...] diante de peculiaridades da causa relacionadas à impossibilidade ou à excessiva dificuldade de cumprir o encargo nos termos do caput ou à maior facilidade de obtenção da prova do fato contrário, poderá o juiz atribuir o ônus da prova de modo diverso, desde que o faça por decisão fundamentada, caso em que deverá dar à parte a oportunidade de se desincumbir do ônus que lhe foi atribuído. (BRASIL, 2015)

Comentando o dispositivo supra mencionado, Dinamarco e Lopes (2016, p. 184) afirmam que,

[...] as peculiaridade da causa ali referidas são apreciadas pelo juiz em cada caso segundo sua sensibilidade às realidades do processo. São fatores subjetivos, como a própria hipossuficiência econômico-financeira de uma das partes, seu despreparo ou inexperiência etc, ou fatores objetivos 
relacionados com a própria causa, dificuldades para a obtenção de certos documentos, etc.

Seja qual for a hipótese de inversão do ônus da prova, a alteração da regra geral não poderá tornar impossível a desincumbência do ônus probatório, eis que tal regra foi criada justamente para possibilitar a comprovação de fatos que diante da hipossuficiência, despreparo e dificuldade na obtenção de documentos, seja impossível a comprovação de determinados fatos.

\subsection{DO ÔNUS DA PROVA NO DIREITO PROCESSUAL DO TRABALHO}

A regra contida na Consolidação das Leis do Trabalho (CLT) referente ao ônus probatório é extremamente simplista, constando em seu artigo 818 apenas que, “[...] o ônus de provar as alegações incumbe à parte que as fizer" (BRASIL, 1943), aplicando-se, assim, subsidiariamente o disposto no Código de Processo Civil, desde que compatível com as normas processuais trabalhistas, nos termos dos artigos 769 da Consolidação Trabalhista e 15 do Código de Processo Civil.

Importante salientar que com a chegada do novo Código de Processo Civil de 2015, houve alteração na aplicação subsidiária dos artigos já sedimentados do código de 1973, iniciando-se os primeiros passos doutrinários e jurisprudenciais na análise da compatibilidade dos dispositivos do novo diploma legislativo no processo trabalhista, possibilitando uma melhora na prestação jurisdicional trabalhista com um processo mais justo e efetivo (SCHIAVI, 2016, p. 154-155).

Com a alteração do código processual civil, a aplicação já 
sedimentada do antigo artigo 333 do CPC/73 permanece com a entrada em vigor do $\mathrm{CPC} / 15$ devido à manutenção da mesma letra de lei em seu artigo 373, sendo a atual doutrina pacífica neste sentido,

Diz a doutrina clássica que o sucesso do processo depende da qualidade da atividade probatória da parte. De outro lado, é bem verdade que a necessidade da prova depende do embargo probatório das partes no processo e da avaliação das razões da inicial e da contestação (arts. 818 da CLT e 373 e 374 do CPC) (SCHIAVI, 2016, p 669).

De igual posicionamento é o entendimento do Egrégio Tribunal Superior do Trabalho,

Demonstrado no agravo de instrumento que o recurso de revista preenchia os requisitos do art. $896 \mathrm{da}$ CLT, dá-se provimento ao agravo de instrumento, para melhor análise da arguição de violação do art. 818 da CLT c/c o art. 333 do CPC/1973 (atual art. 373 do CPC/2015), suscitada no recurso de revista. Agravo de instrumento provido. (TST - ARR: 17649720135090322, Relator: Mauricio Godinho Delgado, Data de Julgamento: 25/05/2016, $3^{\text {a }}$ Turma, Data de Publicação: DEJT 03/06/2016).

Que orienta as decisões proferidas pelos Tribunais Regionais do Trabalho, vejamos:

Admitida a prestação de serviços e alegada a ausência de subordinação, compete à parte ré o ônus da prova quanto aos fatos impeditivos do direito do autor (art. 373, II, do NCPC). Não tendo se desincumbido com êxito do seu encargo probatório, impõe-se o reconhecimento do vínculo de emprego. Recurso da 
parte autora a que se dá provimento. (TRT9 - RO: 00866-2015-749-09-00-0-PR, Relator: Francisco Roberto Ermel, Data de Julgamento: 05/10/2016, Sexta Turma, Data de Publicação: 14/06/2016)

ÔNUS DA PROVA. REGRA GERAL DO ART. 818, DA CLT E 373, II, DO CPC/2015. A prova das alegações incumbe à parte que as fizer, competindo à parte autora especificamente o ônus de comprovar o fato constitutivo de seu direito, enquanto à reclamada incumbe demonstrar fatos impeditivos, modificativos ou extintivos do direito postulado. Desincumbindo-se a ré de seu encargo probatório, impõe-se a rejeição do recurso autoral. (TRT1 - RO: 00100154320145010015 RJ, Relator: REDATOR, Data de Julgamento: 08/06/2016, Terceira Turma, Data de Publicação: 14/06/2016).

No que tange ao ônus da prova no processo trabalhista, além da aplicação do princípio do interesse, segundo o qual cabe ao autor a comprovação do fato constitutivo de seu direito e ao réu à existência de fato impeditivo, modificativo ou extintivo do direito do autor, o conhecimento adquirido pelo magistrado ao longo de sua carreira também é utilizado na presunção de determinadas situações ou fatos, corroborando na valoração e interpretação das provas nos autos, existindo expressa previsão na CLT quanto a possibilidade de utilização da máxima de experiência do juiz no artigo 852-D, in verbis:

O juiz dirigirá o processo com liberdade para determinar as provas a serem produzidas, considerado o ônus probatório de cada litigante, podendo limitar ou excluir as que considerar excessivas, impertinentes ou protelatórias, bem como para apreciá-las e dar especial valor às regras de experiência comum ou 
técnica. (BRASIL, 1943)

Embasado no dispositivo supramencionado Carlos Henrique Berreza Leite (2008, p. 562) afirma que o referido artigo é claro quanto à possibilidade do magistrado autorizar a inversão do ônus da prova no âmbito trabalhista, tecendo uma importante advertência "[...] o princípio em tela só tem lugar quando não existirem outras provas nos autos suficientes à formação do convencimento do juiz acerca dos fatos alegados pelas partes".

Por outro lado, Schiavi (2016, p. 667-668) considera as máximas de experiência como um poderoso aliado do magistrado na valoração e interpretação das provas, apontando como exemplo a possibilidade do juiz afastar a veracidade do depoimento de uma testemunha com base no conhecimento adquirido ao longo dos anos, nada se referindo quanto à possibilidade de inversão do ônus da prova.

Para o autor (2016, p. 674), a distribuição dinâmica do ônus da prova decorre da aplicação do princípio da aptidão da prova, segundo o qual quem deverá produzir a prova é aquele que possui melhores condições materiais ou técnicas para produzi-la, não se tratando da inversão do ônus da prova previsto no Código de Defesa do Consumidor. Segundo afirma, o princípio da aptidão para a prova,

Trata-se em verdade da superação da regra do ônus da prova prevista nos arts. 818 da CLT e 373 do CPC, à luz dos princípios constitucionais do acesso à justiça, contraditório, ampla defesa e igualdade substancial dos litigantes, uma vez que no processo, em determinadas circunstâncias, a prova pode ser produzida com maior facilidade e efetividade por uma parte a qual não detém o ônus da prova. (SCHIAVI, 
Conforme entendimento do autor, o princípio da aptidão da prova é perfeitamente aplicável no processo do trabalho em decorrência da hipossuficiência e da dificuldade probatória de produção de determinadas provas pelo trabalhador, citando como exemplo a prova do salário e da jornada de trabalho.

Com relação a inversão do ônus da prova propriamente dita, a inversão convencional disposta no artigo $373, \S 3^{\circ}$, do Código de Processo Civil, que consiste na alteração das regras de distribuição do ônus por convenção das partes, não tem aplicação no processo trabalhista (SCHIAVI, 2016, p. 688).

No entanto, há aplicação da regra da inversão do ônus da prova prevista no Código de Defesa do Consumidor, em razão da compatibilidade com os princípios processuais do trabalho, que preveem a hipossuficiência do trabalhador e a aptidão da prova, exigindo-se na justiça laboral os mesmos requisitos previstos no artigo $6^{\circ}$, inciso VIII, da Lei $\mathrm{n}^{\circ}$. 8.078/90, quais sejam, a faculdade do magistrado e os requisitos alternativos da hipossuficiência ou verossimilhança da alegação.

A aplicação da inversão do ônus comprobatório com fulcro no dispositivo consumerista é aceita pelo Tribunal Superior do Trabalho e pelos Tribunais Regionais do Trabalho, conforme se infere nas decisões abaixo colacionadas:

Estabelecidas tais premissas, tenho que, embora a ausência de fiscalização seja fato constitutivo do direito do autor e, nos termos do artigo 818 da CLT c/c artigo 333, I do CPC, dele seja o ônus comprová-la, invertese o ônus da prova com fulcro no artigo $6^{\circ}$, inciso XVIII do CDC, por 
se tratar de fato negativo, de difícil comprovação, e considerando-se a hipossuficiência do trabalhador e verossimilhança da alegação. (TST RR: 100148720135010049, Relator: Min. João Batista Brito Pereira, $5^{\text {a }}$ Turma, Data de Publicação: DEJT 30/09/2016).

Ressalte-se que nos termos do princípio da aptidão da prova, deve ser imputado o ônus de provar, à parte que possui maior capacidade para produzi-la, no caso, o Poder Público. Resta clara sua aplicação no processo do trabalho, diante da teoria do diálogo das fontes com o sistema de defesa do consumidor, e que autoriza a inversão do ônus da prova, nos termos do artigo $6^{\circ}$, VIII do CDC, “(...) quando, a critério do juiz, for verossímil a alegação ou quando for ele hipossuficiente, segundo as regras ordinárias de experiências". Assim, tendo em vista a similitude de condição jurídica do trabalhador e do consumidor, eis que estão em nítida situação de vulnerabilidade, afigurase cabível aplicar o artigo $6^{\circ}$, VIII do CDC ao processo trabalhista, o qual, aliás, é absolutamente consentâneo com os mais basilares princípios do Direito do Trabalho, razão pela qual é muito mais razoável atribuir à Administração Pública o dever de comprovar a efetiva fiscalização do cumprimento das obrigações pela empresa fornecedora da mão de obra, do que imputar ao empregado o dever de provar a omissão do Poder Público, o que redunda, em última analise, a atribuir ao trabalhador, ônus de prova de fato negativo. (TRT2 - RO: 27615820145020090 SP, Relator: Des. Ivani Contini Bramante, $4^{\text {a }}$ Turma, Data de Publicação: 23/09/2016).

Embora as atuais decisões utilizem como fundamentação a lei consumerista, com o advento do Código de Processo Civil de 2015, a distribuição dinâmica da prova no âmbito trabalhista poderia ser realizada 
com fulcro no parágrafo $1^{\circ}$, do artigo 373 , do CPC, que possibilita a distribuição dinâmica da prova ao dispor que,

Nos casos previstos em lei ou diante de peculiaridades da causa relacionadas à impossibilidade ou à excessiva dificuldade de cumprir o encargo nos termos do caput ou à maior facilidade de obtenção da prova do fato contrário, poderá o juiz atribuir o ônus da prova de modo diverso, desde que o faça por decisão fundamentada, caso em que deverá dar à parte a oportunidade de se desincumbir do ônus que lhe foi atribuído. (BRASIL, 2015)

Sobre tal possibilidade Schiavi (2016, p. 691) apenas aponta ao final do capítulo "da inversão do ônus da prova no Direito Processual do Trabalho" a existência do referido dispositivo e a sua inclusão "[...] seguindo a posição majoritária da doutrina e da jurisprudência", não tecendo qualquer posicionamento quanto sua utilização no processo trabalhista.

Independentemente do fundamento legal utilizado, a inversão do ônus da prova é possível e frequentemente utilizada perante a Justiça Laboral, ficando a critério do juiz, segundo seu livre convencimento e mediante decisão fundamentada, inverter o ônus probandi, havendo, ainda, situações em que a inversão do ônus da prova já se encontra sedimentada mediante súmula, como pode se observar, por exemplo, no teor das súmulas 212, 338, 443 e 460 do TST.

Ante a importância da prova na efetividade ao acesso à Justiça justa e a tutela do direito da parte hipossuficiente na comprovação do fato constitutivo de seu direito, a inversão do ônus da prova deve ser aplicada aos casos em que a impossibilidade comprobatória por parte do 
empregado possa lhe trazer prejuízos, como nas situações já sumuladas (despedimento, jornada de trabalho, dispensa discriminatória, vale transporte...) e em casos em que o magistrado notar peculiaridades da causa relacionadas à impossibilidade ou à excessiva dificuldade de cumprir o encargo provatório, como nas situações de assédio moral.

\subsection{DA INVERSÃO DO ÔNUS DA PROVA EM SITUAÇÕES DE ASSÉDIO MORAL}

Conforme analisado no item 2 do presente artigo, o assédio moral é uma prática recorrente no meio ambiente do trabalho, não sendo poucos os relatos de trabalhadores que são assediados por seus colegas de profissão, seus superiores hierárquicos e até mesmo seus subordinados, seja no âmbito privado e até mesmo em instituições públicas, restando nítida a violação aos direitos da personalidade do trabalhador: sua liberdade, honra, intimidade, moral, imagem, enfim, seu direito ao respeito e à dignidade humana.

Em decorrência da gravidade do ato de assediar, nem sempre o agressor expõe o ato em público, sendo comum a agressão através de ofensas particulares, realizadas em ambientes reservados, onde a produção de provas é ainda mais dificultada pela ausência de testemunhas.

Seja uma agressão reservada ou pública, ambas as formas de assediar ofendem a dignidade do trabalhador, ocasionando-lhe na maioria das vezes diversos problemas patológicos e psicológicos, como a depressão.

Silva (2015, p. 31) expõe sua perplexidade ante a reação de algumas vítimas, ao afirmar que: 
O que se faz surpreendente, em um primeiro contato, é o fato de algumas vítimas se conformarem com o seu destino, malgrado toda a humilhação e sofrimento. Em uma relação com indivíduos perversos, não há equilíbrio, mas tão somente subjugação, e impossibilidade de reação por parte da vítima. Os mecanismos de desvalorização e culpa serão o ponto fraco que será explorado pelo indivíduo perverso em suas vítimas. assediado,

No mesmo norte, Rufino (2011, p . 61) relata que o empregado

[...] fica acuado diante da ideia de perda do emprego, tolerando a violação desses direitos. Com isso, dificilmente o trabalhador assume e divulga o fato de ser vítima dessa violência, e sobretudo, fica prejudicada a prova do fenômeno, em razão da subordinação a que a vítima se submente no contrato de trabalho.

Com a conformação da vítima e seu acuamento frente aos atos do agressor, além da continuidade do assédio, fica prejudicada a prova do ato, como bem apontado por Rufino, fazendo-se decorrer o tempo sem o planejamento da produção de provas a serem utilizadas em juízo.

Diante desta hipossuficiência probatória, a jurisprudência vem admitindo a gravação de conversas feitas por um dos interlocutores, mesmo sem o conhecimento do outro, como se observa na decisão abaixo colacionada,

RECURSO DE REVISTA. GRAVAÇÃO AMBIENTAL. DESCONHECIMENTO DE UM DOS INTERLOCUTORES. PROVA LÍCITA. A gravação de conversa feita por um dos interlocutores 
sem o conhecimento do outro para fins de comprovação de direito não possui a mácula da ilicitude. Hipótese em que a decisão recorrida alinha-se com a jurisprudência do TST e do excelso STF que no RE583937, DJe 18/12/2009, reafirmou a validade desse meio de prova. Recurso de revista não conhecido" (RR-162600-35.2006.5.06.0011, Relator Ministro Horácio Raymundo de Senna Pires, $3^{\mathrm{a}}$ Turma, DEJT 18/02/2011).

No entanto, tal posicionamento não é pacífico, havendo tribunais que permanecem considerando a gravação não autorizada como prova ilícita, sequer aplicando o princípio da proporcionalidade para ponderar os valores envolvidos no caso concreto.

Sobre a aplicação do princípio da proporcionalidade Schiavi (2016, p. 714) expõe seu entendimento ao afirmar que,

Acreditamos que a regra da proporcionalidade é a melhor para se admitir a pertinência da prova obtida por meio ilícito no processo, pois nenhuma regra processual é absoluta, devendo ser sopesada em confronto com outro direito fundamental. Além disso, prestigia a justiça da decisão no caso concreto, possibilitando ao juiz, diante do conflito de princípios, escolher entre dois males, o menor, ou escolher a melhor justiça.

No mesmo sentido é o posicionamento de Leite (2008, p. 555) apontando ao discorrer que o princípio da proibição da prova obtida ilicitamente

[...] tem sido mitigado por outro: o princípio da proporcionalidade ou razoabilidade, segundo o qual não se deve chegar ao extremo de negar validade a 
toda e qualquer prova obtida por meios ilícitos, como por exemplo, uma gravação sub-reptícia utilizada por empregada que deseja fazer prova de que fora vítima de assédio sexual pelo seu empregador ou superior hierárquico, sem o conhecimento deste.

Inobstante a gradativa evolução processual na admissão das gravações unilaterais, o conformismo da vítima e seu desconhecimento tecnológico (e muitas vezes jurídico) nem sempre permite a realização das referidas gravações, dificultando a comprovação do assédio moral no âmbito judicial em decorrência da insegurança da prova testemunhal, seja pelo motivo de certos assédios ocorrerem em ambiente velado, seja pelo temor da própria testemunha em relatar os fatos e, em consequência, perder seu emprego.

Em situações como a presente, ante a dificuldade comprobatória decorrente de peculiaridades da causa relacionadas à impossibilidade ou à excessiva dificuldade de cumprir o encargo probatório, a inversão do ônus da prova quanto a higidez do meio ambiente laboral poderia ser sumulada ou ao menos aplicada pelo magistrado, tanto para possibilitar uma decisão mais justa, quanto para obstaculizar a violência cometida pelos empregadores.

Utilizando das palavras de Carlos Alberto Reis de Paula, Schiavi (2016, p. 674-675) corrobora com nosso entendimento afirmando que,

A aplicação no ônus da prova do princípio da aptidão atende ao escopo social do processo, que é eliminar conflitos mediante critérios justos [...]. O fundamento para aplicação do princípio da aptidão está na justiça distributiva aliada ao princípio da igualdade, cabendo a cada parte aquilo que normalmente lhe resulta mais fácil. $\mathrm{O}$ critério será o da proximidade 
real e de facilidade do acesso às fontes de prova. Indiscutivelmente, o princípio será aplicado todas as vezes em que o empregado não pode fazer a prova a não ser através de documento ou coisas que a parte contrária detém. Partindo do princípio da boa-fé, que informa a conduta processual dos litigantes, todas as vezes que o documento, por seu conteúdo, for comum às partes, haverá também a inversão do ônus da prova, compelindo ao empregador colacioná-lo, sob pena de serem admitidas como verdadeiras as alegações feitas pelo empregado.

Apesar de não corresponder ao assédio moral em si, a aplicação do princípio da aptidão para a invenção do ônus da prova já vem sendo utilizado em situações em que há grande dificuldade comprobatória por parte do trabalhador, aplicando-se, segundo entendimento constante no enunciado 41 da $1^{\text {a }}$ Jornada de Direito Material e Processual do Trabalho realizada no TST a inversão do ônus da prova em ações acidentárias em que há pleito de reparação de danos morais e materiais, vejamos: “ RESPONSABILIDADE CIVIL. ACIDENTE DO TRABALHO. ÔNUS DA PROVA. Cabe a inversão do ônus da prova em favor da vítima nas ações indenizatórias por acidente do trabalho".

Com fundamento no referido enunciado, é possível localizar diversas ações acidentárias empregando a inversão do ônus probatório, o que facilita a comprovação do acidente do trabalho.

No entanto, embora o assédio moral também corresponda a um desiquilíbrio do meio ambiente laboral e deixe severas sequelas no trabalhador assediado, não foi possível localizar qualquer decisão que apontasse a inversão do ônus da prova nesta situação.

Mantendo-se o onus probanti para o trabalhador, existem poucas decisões que reconhecem a ocorrência do assédio frente ao número de 
ocorrências conhecidas, sendo vasta a quantidade de acórdãos que negam o pleito de condenação por ausência de prova robusta, demonstrando a dificuldade comprobatória do trabalhador, vejamos algumas.

DANOS MORAIS. ASSÉDIO MORAL. PROVA TESTEMUNHAL. CONHECIMENTO DE FATOS POR INTERMÉDIO DO AUTOR DA AÇÃO. FRAGILIDADE DO DEPOIMENTO. INDENIZAÇÃO INDEVIDA. O assédio moral, como espécie do gênero dano moral, assim como este, demanda, para seu reconhecimento, prova clara e robusta da conduta ilícita, ônus que pertence ao autor da pretensão ao pagamento de indenização por danos morais, nos termos do art. 818 da CLT e art. 333, I, do CPC. Nesse contexto, não é suficiente, para o deferimento da indenização em apreço, depoimento de testemunha que, além de negar ter presenciado a prática dos atos ilícitos alegados como ensejadores de danos à esfera extrapatrimonial obreira, narra fatos de somenos relevância (meros indícios, quando muito) dos quais teve conhecimento, não pessoalmente, mas por intermédio do próprio autor da ação, circunstância que o fragiliza como meio de prova no processo. Ônus da prova do qual não se desincumbiu, portanto, o autor. Indenização por danos morais indevida. (TRT-PR-27486-2014-02809-00-3-ACO-18505-2015 - 6A. TURMA. Relator: SUELI GIL EL RAFIHI. Publicado no DEJT em 09-06-2015).

Em situações como a relatada, certamente o assédio era velado, inexistindo quem pudesse testemunhar em favor da vítima, sendo conhecidos os fatos de forma indireta, não sendo desincumbido o ônus probatório pela fragilidade do depoimento, também constatado no processo abaixo, 
ASSÉDIO MORAL. PROVA ROBUSTA. Para caracterização do assédio moral, deve, o reclamante, produzir prova cabal e robusta dos fatos persecutórios capazes de ensejar o reconhecimento do alegado dano (arts. 818, da CLT, e 333, I, do CPC), o que não ocorreu no presente caso. As testemunhas indicadas pelo reclamante foram visivelmente contraditórias entre si, ao passo que as ouvidas pela ré asseguraram a inocorrência de qualquer ato discriminatório, principalmente, passível de reparação. Recurso do reclamante a que se nega provimento. (TRTPR-00653-2011-655-09-00-8-ACO-02171-2012 - 6A. TURMA. Relator: SUELI GIL EL-RAFIHI. Publicado no DEJT em 24-01-2012).

Como, geralmente, o assédio ocorre de forma velada, dificilmente as testemunhas saberão descrever o ato precisamente, o que não afastará a afronta aos direitos da personalidade do empregado pelo agressor e os danos suportados pela vítima.

Além destas situações, há diversos outros casos em que sequer foram ajuizados ante ao temor da dificuldade comprobatória, que por vezes retira a coragem do trabalhador lutar por seus direitos, acovardando-o frente aos atos lesivos sofridos, permitindo a continuidade da humilhação e do menosprezo, deixando sequelas que afetam os valores íntimos de sua subjetividade e estimulando o agressor na continuidade do assédio ante a impunidade.

A transferência do ônus probante para o empregador, que deverá comprovar tão somente a existência de um meio ambiente hígido (sem a necessidade de provar a não ocorrência dos fatos alegados pelo trabalhador), facilitará a demonstração em juízo das condições do meio 
ambiente laboral, auxiliando o magistrado na busca da verdade real, evitando tanto a impunidade do agressor, quanto a condenação exacerbada dos empregadores.

\section{CONCLUSÕES}

Com fundamento no artigo 225 da Constituição da República, é dever do Poder Público e da coletividade defender e preservar o meio ambiente para as presentes e futuras gerações, estendendo tal imposição ao meio ambiente do trabalho, local em que o ser humano despende grande parte de sua vida e que, portanto, deve ser igualmente equilibrado, priorizando a saúde física, psíquica e social dos trabalhadores, resguardando sua personalidade das práticas nocivas adotadas no ambiente laboral, como o assédio moral.

Infelizmente, a defesa e preservação não vem sendo realizada com sucesso, eis que o assédio moral tem se tornado uma prática cada vez mais comum no meio ambiente de trabalho, desequilibrando-o e, consequentemente, abalando a qualidade de vida do trabalhador, reduzindo sua saúde física, psicológica e mental, afetando seus direitos da personalidade de forma significativa, lesando, ainda, o valor social do trabalho e a dignidade da pessoa humana.

Como consequência da reiterada agressão moral sofrida, o trabalhador, muitas vezes intimidado, ou até mesmo sentindo-se culpado e merecedor da violência, passa a tolerar a atitude desprezível do agressor até o momento em que pede demissão ou afasta-se do trabalho por problemas de saúde.

Quando ciente de seu direito, visando a reversão do pedido de demissão ou apenas o pleito de indenização pelos danos sofridos, o 
trabalhador novamente vê-se fragilizado ante a dificuldade comprobatória das lesões sofridas, seja por ausência de pessoas que acompanharam a violência moral, seja por temor das testemunhas deporem contra seu empregador e, após, perderem o emprego.

É certo ser vedada a demissão decorrente de testemunho desabonador à empresa, no entanto, novamente nos deparamos com a dificuldade comprobatória frente ao poder diretivo do empregador.

Conforme fundamentando ao logo do presente, é possível a aplicação da inversão do ônus da prova prevista no artigo $6^{\circ}$, inciso VIII do Código de Defesa do Consumidor, bem como no artigo 373, parágrafo primeiro, do Código de Processo Civil, ficando a critério do juiz, segundo seu livre convencimento e mediante decisão fundamentada, atribuir o ônus da prova de modo diverso.

Portanto, ante a nítida hipossuficiência do trabalhador na comprovação do assédio moral, decorrente da peculiaridade do ato, e a necessidade de tutela da dignidade dos trabalhadores e de seus direitos da personalidade, entendemos que a inversão do ônus da prova em situações de assédio moral, imputando ao empregador o ônus de comprovar a higidez do ambiente de trabalho, seja a medida adequada para possibilitar uma decisão mais justa no processo e, assim, indiretamente obstaculizar a violência cometida no meio ambiente laboral, sem o avanço da litigiosidade trabalhista.

\section{REFERENCIAS}

ARAÚJO, Adriane Reis. Assédio moral organizacional. IN: Revista TST, vol. 73, n. 2, p. 203-214. Brasília, abr/jun 2007.

BARRETO, Maria Silveira. Uma jornada de humilhações. São 
Paulo: Fapesp; PUC, 2000.

BITENCOURT, Manoela de. Aplicação dos direitos da personalidade nas relações de trabalho. $I N$ : Justiça do Direito, vol. 26, n. 1, p. 52-67. Passo Fundo: Ed. Universidade de Passo Fundo, 2012.

BITTAR, Carlos Alberto. Os direitos da personalidade. 8. ed. São Paulo: Saraiva, 2015.

BRASIL. Constituição da República Federativa do Brasil, de 5 de outubro de 1988. Disponível em: <http://www.planalto.gov.br/ ccivil_03/constituicao/constituicaocompilado.htm $>$. Acesso em 30 mar. 2016.

\section{. Decreto-Lei $n^{0} . \mathbf{5 . 4 5 2}$, de $1^{\circ}$ de maio de 1943.}

Aprova a Consolidação das Leis do Trabalho. Disponível em: $<$ http:// www.planalto.gov.br/ccivil_03/decreto-lei/Del5452.htm>. Acesso em 05 set.. 2016.

. Lei 5.869, de 11 de janeiro de 1973. Institui o Código de Processo Civil - Revogada pela Lei 13.105/15. Disponível em: <http://www.planalto.gov.br/ccivil_03/leis/L5869.htm>. Acesso em 05 set. 2016.

. Lei ${ }^{0}$. 6.938, de 31 de agosto de 1981. Dispõe sobre a Política Nacional do Meio Ambiente, seus fins e mecanismos de formulação e aplicação, e dá outras providências. Disponível em: $<$ http://www.planalto.gov.br/ccivil_03/leis/L6938.htm>. Acesso em 05 set.. 2016.

Lei 13.105, de 16 de março de 2015. Código de Processo Civil. Disponível em: <http://www.planalto.gov.br/ ccivil_03/_ato2015-2018/2015/lei/113105.htm>. Acesso em 05 set. 
2016.

CINTRA, Antonio Carlos de Araújo Cintra; GRINOVER, Ada Pellegrini. Teoria geral do processo. $24^{\mathrm{a}}$ ed. São Paulo: Malherios Editores, 2008.

DELGADO, Mauricio Godinho. Curso de direito do trabalho. São Paulo: LTr, 2013.

DINAMARCO, Cândido Rangel; LOPES, Bruno Casconcelos Carrilho Lopes. Teoria geral do novo processo civil. São Paulo: Malheiros Editores, 2016.

FIORILLO, Celso Antonio Pacheco e RODRIGUES, Marcelo Abelha. Manual de Direito Ambiental e Legislação Aplicável. São Paulo: Max Limonad, 1997.

FIORILLO, Celso Antonio Pacheco. Curso de direito ambiental brasileiro. 15. ed. São Paulo: Saraiva, 2014.

HIRIGOYEN, Marie-France. Mal-estar no trabalho: redefinindo o assédio moral. Tradução Rejane Janowitzer, Rio de Janeiro: Bertrand Brasil, 2012.

LEITE, Carlos Henrique Bezerra. Curso de direito processual do trabalho. São Paulo: LTr, 2008.

NASCIMENTO, Amauri Mascaro do. A defesa processual do meio ambiente do trabalho. IN: Revista LTr: legislação do trabalho, vol. 63, n. 5, p. 583-587. São Paulo: LTr, 1999.

RUFINO, Regina Célia Pezzuto. Assédio moral no âmbito da empresa. São Paulo: LTr, 2011. 
SCHIAVI, Mauro. Manual de direito processual do trabalho. São Paulo: LTr, 2010.

SCHIAVI, Mauro. Manual de direito processual do trabalho. São Paulo: LTr, 2016.

SILVA, Leda Maria Messias da. O cumprimento da função social do contrato no tocante ao meio ambiente do trabalho. $I N$ : Revista jurídica Cesumar, v. 8, n. 1, p. 103-116 Mestrado. Jan/jun. 2008.

SILVA, Leda Maria Messias da; SILVA, Lanaira da. O assédio moral na administração pública: um livro em prol da extinção dessa praga. São Paulo: LTr, 2015.

SILVA, Leda Maria Messias da; CARVALHO, Gisele Mendes de et al. Assédio moral no ambiente de trabalho: uma proposta de criminalização. Curitiba: J. M. Livraria Jurídica, 2013.

THEODORO JÚNIOR, Humberto. Curso de direito processual civil: Teoria geral do direito processual civil e processo de conhecimento. $47^{\mathrm{a}}$ ed. Rio de Janeiro: Forense, 2007.

Como citar: PIRES, Marcela Sandri. SILVA, Leda Maria Messias da. O assédio moral e a inversão do ônus da prova. Revista do Direito Público, Londrina, v. 12, n. 2, p. 216-249, ago. 2017. DOI: 10.5433/1980-511X.2017v12n2p216

Recebido em: 15/12/2016

Aprovado em: 29/05/2017 